\title{
The great experiment - the Trinidad experiment Art, abolition and racial indenture across archipelagoes
}

\section{Tao Leigh Goffe}

An interview with mixed media artist Andrea Chung

Tao Leigh Goffe is assistant professor of literary theory and cultural history, Cornell University

\section{ABSTRACT}

Scholar Tao Leigh Goffe, co-editor of the Journal of Indentureship and Its Legacies, interviews mixed media visual artist Andrea Chung who is based in the United States. Connecting the histories of the Great Experiment of indenture in Mauritius and the Trinidad Experiment of Chinese indentureship in the Caribbean, the two discuss the history of labour exploitation and the abolition of racial slavery comparatively across oceans. Themes include those tackled in Chung's artwork spanning colonialism, loss, motherhood, Afro-Asian heritage, and the material culture of global indentureship.

\section{KEYWORDS}

Afro-Chinese, art of indenture, Mauritius, coolitude, Sino-Mauritian, Creole

Connect to Andrea's work at https://andreachungart.com

\section{AC:}

My name is Andrea Chung. I am a visual artist currently living in San Diego. My background is that my father is from Jamaica, and 


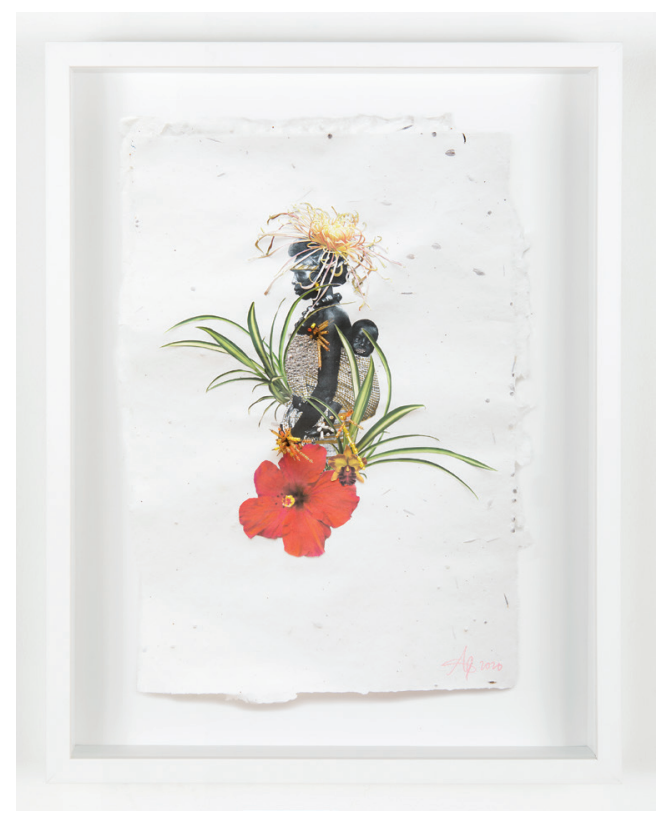

An image from Andrea Chung's collection Colostrum. (c) Andrea Chung 2021

my mother is from Trinidad and I make work that is invested in processing materiality, specifically things that are related to island nations such as the Caribbean and Mauritius, after having spent some time there. I take colonialism and how it has impacted the land, the people, how it has impacted us, psychologically, as well as physically. I'm a huge supporter of supporting us, because I think that the Caribbean community is quite small in comparison to everything else here in the United States. So, I think it's important that we all support each other. And then you're (TLG) Chinese Caribbean, so it's like, 'Yes, I don't have to explain anything anyway.' It's not complicated, like somebody clearly married or had sex with somebody that was Asian. And I actually told somebody that once when she said, 'how did you get your last name?' I said, 'Well, my parents, fucked, and here I am.' This was a crass question. 


\section{TLG:}

Having a Chinese first name, Tao, I think comes with different ideas of what people expect, rather than having a Chinese last name.

\section{AC:}

They don't know what to do, though. They really don't. They don't know what box to put me in. So, I'm just, you know, I get real, depending on how you ask the question that's pretty much the answer you're going to get. If you ask me in a really dumb way, I'm going to give you a dumb answer to make you understand what you just asked me. Read a book. It's not that complicated.

\section{TLG:}

That brings me to the next question, which is the question of dreams, and it's a question of inheritance. In my engagement with your work in the article I wrote entitled 'Sugarwork: The Gastropoetics of AfroAsia After the Plantation', that is something that I drew heavily upon, thinking about what Afro-Chinese heritage means for you, for Cuban artist Maria Magdalena Campos-Pons. Could you speak to if you feel there's any sort of island or archipelagic inheritance?

\section{AC:}

I think, unfortunately, the thing that has been passed down, to me the most has been trauma, and the kinds of trauma that we've inherited, that has unfortunately become a legacy in my part of the family. And, you know, a lot of the work that I make now, I think I wanted my son to really understand where he comes from. Like, I understand a lot of the issues that have been traumatic to my parents, particularly my father. I understand why they respond the way that they do to certain things like their expectations of their children. But I also feel like, in some ways, they cannot rid themselves of that trauma. And that becomes like, 
a generational trauma that's passed down. And it's like, at what point does that stop. And I feel that, you know, I grew up in a place that didn't have a lot of Caribbean people, I grew up in Houston. And when I moved to New York, it was sort of reassuring that there were other people there that I didn't have to explain myself to, which is great. And then I started to make a lot of friends that were from the Caribbean, not necessarily from Jamaica, but we have that bond. You know, like we have that bond of, of being of an island and all of the things that came with that. And so, I want him to know those things, but I want him to know it without the trauma that I had to inherit, and I want him to inherit the knowledge of where he's from and understanding and actually like allowing him the ability to have the freedom to do and dream in the way that he wants to, as opposed to my specific expectations of him.

\section{TLG:}

There's a genealogy that makes complete sense. In the sense of a genealogy and your son is that actual genealogy.

\section{AC:}

He is completely my legacy. I think when artists talk a lot about, like, being concerned of their legacy, they're thinking of their work. But for me, like, he is my work. You know, he's the single most amazing thing I've ever made. And everything that I put into my work, you know, I've already put into him, so I want him to, know the things that we've gone through and normalise his last name, and I want all of those to seem normal for him and for him to really understand who he is from, his family, at least in this part of his family.

\section{TLG:}

Right. And I mean, I think I've seen some of your work where you actually feature him. So, could you talk about that and using photographs of your son and perhaps talking about the specific art? 


\section{AC:}

That's a pretty recent thing, and I'm working on some cyanotypes that I had sort of just been playing around with different ideas, and I was kind of fascinated with the idea of Drexciya. And for anyone that's unfamiliar with it. Drexciya was created by a Detroit band, they were sort of like an Afro-futurist group, and they called themselves Drexciya. And the idea was, like, sort of this sort of, like Afro-futuristic Atlantis, in the water. And the people who populated the kingdom were those who jumped over the slave ships or were thrown over. And I was always fascinated with the idea of, you know, the, the people who were in the water that they could sort of create their own colony, and in some ways, their own kingdom, where they would be free and like, what would they look like? What would their children look like? I was just, I don't know, it was a thought that always stuck into my head. And the more I started doing research, that's how I found out about Drexciya, the group and that's how I found out about some of the work that Ellen Gallagher has done on Drexciya. I really was interested in using images of children or young, young kids to sort of create what they would look like. So they sort of morph into aspects of things that are underwater, like corals. And, you know, lionfish and things like that. I didn't want to be the fish woman, who only made work about lionfish. So, I wanted to sort of push the idea of what I had started with the lionfish in the cyanotypes, and push it into, you know, thinking of Drexciya, and what would that life be like? Would they be our guardians? You know, would their lives be better? Because they weren't, they weren't enslaved in the way that we were. So yeah, it was just sort of a play on that. And I just felt like, well, he's there. Let me just use him as a model to sort of experiment with. And I really liked the way that that first cyanotype test came out. I'm trying to create a series with very oversized cyanotypes that are maybe, like, 40 by 60 inches. And just see how that goes, like, put them all in a room and see what that looks like. 


\section{TLG:}

That's so lovely, because I feel there's just so much poetry and history in your artwork. It's so rich and I learned from the examples that you draw on. So related to this question, then could you speak about Le Morne and abolition? Thinking about Mauritius, you know, the fact that you were awarded this prestigious grant, the Fulbright, to go there. Could you talk about how these kinds of historical stories play a role in what you're trying to enact in your art? This idea of escape is something that I feel like I'm hearing a lot.

\section{AC:}

I would like to demystify the Fulbright because I'm always encouraging people to apply for it. It has this idea of being prestigious, but honestly, it's not all that. And I'm not saying that to devalue my accomplishments, but I really do wish that people would apply. Without thinking that it's impossible to get. There's definitely strategy into applying for it. I highly encourage people to apply. You know, a lot of it is just politics. Unfortunately, it's more about making Americans look good to other countries, which really played a role in my experience there. As long as you can show cultural exchange in the country that you choose to apply for you're kind of golden. So yeah, for your students, apply, apply, apply. Oh, yeah, it's really just a lot of smoke and mirrors, honestly. But my particular interest in Mauritius was, and specifically Le Morne. When I applied, I was really interested in - I had, like, honestly, I've been watching Globe Trekker on PBS, because I'm kind of a nerd. And they were on an island and I saw somebody with dreadlocks. And I was like, Oh, they must be somewhere in the Caribbean. And then they were in Mauritius. And I was like, what, where the hell is that? I've never heard that country before. And sure enough, I looked it up. And the similarities to the Caribbean were so unbelievable, down to the food. It was pretty incredible. I mean Mauritius was a former sugar colony as well. There was a depot there where a lot of the Indian indentured servants came through and were 
then dispersed into the Caribbean. Mauritius was sort of seen as an experimental site, which is kind of horrifying to learn while I was there. But I was particularly interested in Le Morne, which is in a village in the southern part of Mauritius that is currently like, populated by Creoles, which would be the equivalent of, of descendants of slaves who were Black. They came mostly from Eastern Africa, like around Mozambique and Madagascar. And the story of Le Morne in particular, is that there were a lot of Maroons there that had escaped and had established a village on top of Mount Le Morne. And it was a very strategic village because it was very hard to climb. And they took up fishing and, you know, different things like that in order to sustain themselves. And when slavery was abolished, the British had sent troops to, quote unquote, let them know that they were free, aka, arrest some of them and re-enslave them. So the people were so frightened that they jumped off the cliff. And so, Le Morne is now an archaeological site, a historical archaeological site, and it's now like a UNESCO World Heritage Site. And after that, when slavery was abolished, one had to do the seven-year apprenticeship. And a lot of the former slaves refused. 'Nah, we're not doing that, like, we've had enough of you. We're not doing this, you're on your own white man, I'm sorry, no, you've lost all your free labour, but it's not happening.' So they continued to take on fishing as their major trade. And I find that to be a very revolutionary act. And it became this trade that was passed down from generation to generation. So, when you go there, you know, you can tell who, whose family members were former slaves. But now it's sort of taken in a way and sort of, they've turned it into a slur and a lot of ways, which I find really interesting. And I feel like all of the stereotypes that are attributed to, to Creoles are very similar to the way that people speak of Black Americans as being like, lazy and savage and I thought that was really interesting, how your act, your revolutionary act could be demonised in that way. So I took a kinship to that and everyone thought we were Creole anyway, we kind of blended it in nicely. It wasn't until we opened our mouths, and people realised we were American. My husband was with me. If you're 
married, your spouse can come with you. It was really interesting that everyone thought that we were Mauritian. So, I think that we had the privilege of really seeing the way that people would respond to us. Mauritius also has a Chinese population that is the exact same Hakka group that has dispersed into the Caribbean as well. And that was so amazing to me, because I got to connect with what felt like my heritage, you know, that I was kind of denied in a lot of ways. And one of our closest friends now, who is Mauritian that we met there, he now moved to the States. So, he's two hours away from us. So, we make sure to see him, you know, as frequently as possible. And he and I, you know, we constantly discuss things related to like Hakka culture. And so, it was an amazing experience. For me, it was probably like one of the best years of my life, it was definitely hard. It has the same challenges of, of any island nation where things run on island time. But it was, it was amazing. I think, because of my husband, who was a history major, history has always been something that has been part of all of my work. I can't separate my work from history in any kind of way. I think a lot of it is because I wanted to initially know more about my family. And now it's become I want my son to really understand. I want him to understand his place in life. So I can't separate that from the practice. It just is what it is.

\section{TLG:}

So, from one island, to another, could you say a bit more then about the work of art or body of work that Le Morne then inspired as you were thinking about this escape?

\section{AC:}

It's funny. I had started making work with sugar when I was in grad school, so like around 2007 and I had been making work to honour my grandmother who had passed from surgery, she had her second leg amputated from gangrene. And so, I was really interested in like, my relationship to sugar. So, then I started looking at you know, the 
Creoles' relationship to sugar and you know, because their fishing trade is sort of now dying out from having foreign ships come into their waters. And actually, just recently, last month, a Japanese oil tanker spilled oil into their waters all through Le Morne. It's devastating to the island. I mean, it really hurts to see the images because that was my base of my research. And Mauritians are incredibly friendly. It's so different than the US, it's the safest place I've ever lived in my life.

You could walk down the street, and someone will talk to you for half an hour. It's dead it's like really devastating to see what has happened there now. And you know, aside from that trade now being you know, destroyed because of the oil and foreigners coming into their waters and stealing their fish, you know, the trade is slowly disappearing. And that act of revolution is um, you know, not only turned on its head to seem as a sort of like, negative thing but to have your trade taken away from you your way of sustaining your life. You know, it's heartbreaking. So, I took sugar and fashioned it into bottles. My husband was chillin' the whole time and was fishing

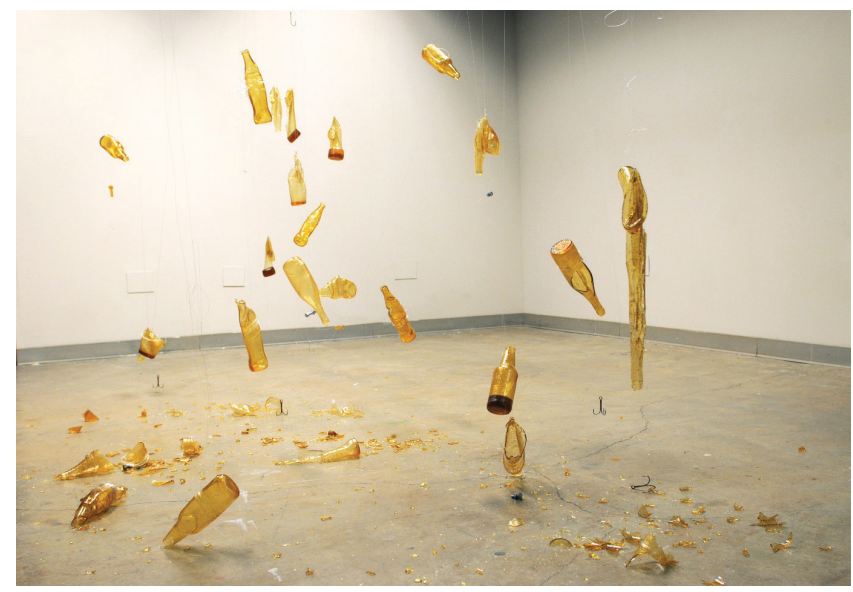

Sink \& Swim. Liquor bottles made out of sugar to recreate a method of fishing used by some Mauritian fishermen. The bottles are accompanied with small metal and sugar replicas of fishing tackle. (c) Andrea Chung 202I 


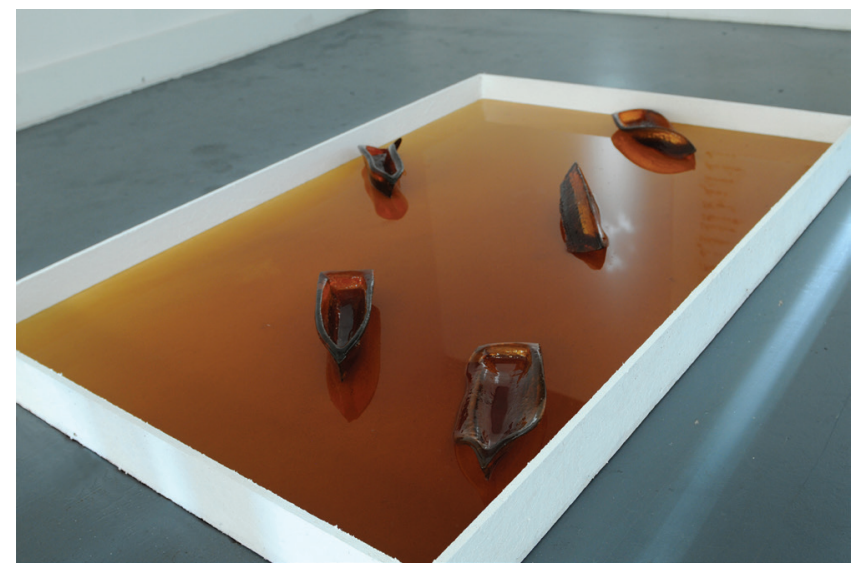

Bato Disik is an installation with a large water bath, filled with multiple boats, similar to the batos used by Mauritian fishermen in their villages, cast out of sugar. Over time the boats disappear, mirroring the disappearance of the fishing trade in Mauritius. (C) Andrea Chung 2021

a lot with local merchants. He was used to fishing using a rod and reel, but they were using bottles to fish with. I recall my father saying that he learned to fish this way in Jamaica as well. You would wrap a fishing line around the bottle, and then cast it into the water and just pull the line up by hand. So that's what I did, I sort of recreated that scenario, using the sugar to create the bottles and suspended them from the ceiling. So, it felt like you were in the water, and over the duration of the exhibition, the bottles melt and start to twist into form and do all these things to sort of mimic the disappearance of that trade. In a lot of ways that act, that ability to use this is a revolutionary act.

\section{TLG:}

It's so evocative of, like you said, this view of the water. And I feel like the water, or the ocean or the sea is a kind of archive, in a 
sense for you, and certainly for me in my work, and I'm actually helping to begin a brand-new peer-reviewed journal with David Dabydeen, Maria del Pilar Kaladeen and Amar Wahab called the Journal of Indentureship and Its Legacies. Could you speak about the question of Mauritius as 'the great experiment', and how that connects to the 'Trinidad experiment?'

\section{AC:}

I didn't realise that there was such a kinship between the two islands until much later. They actually look to the Caribbean as a source of inspiration. So, the idea of 'coolitude' that was created or written about in Trinidad, they very much identify with and they have sort of, have tried to maintain relationship with other academics from Trinidad which is really fascinating. I don't, unfortunately, see the same kind of connections happening within the Chinese community there. I don't know if it's just the smaller number of Chinese Mauritians that are there. But they definitely look specifically to Jamaica, as a source of inspiration and not being ashamed of being descendants of slaves. That was fascinating to me, that people carry shame with that, because I'm like that, that is not something that you asked to be, you know, but there is a shaming about slavery, that tends to happen, because people are descendants of that institution. I don't ... I can't connect to that in any kind of way. So that was really strange.

I think, because of the population it's predominantly Indian, mostly Hindu, but also Muslim. And, and then the next large group is considered the 'other' population, which I thought was also very strange. And that includes Sino-Mauritians and Creoles. They don't specify who they are. So, there's a lot of community separation. They won't tell you that if you're an outsider, but when you're in the country, you can see definite prejudices between communities. We were very lucky to be able to navigate our way through it. But you know, there would be instances, especially my husband, he got it the worst. There would be Indian women that would cut in front of him in line 
at the grocery store and just stand in front of him to pay. It was hilarious. He just was, like, shocked and appalled. I remember that people would stare at him because I think they thought he was Muslim . . . people would call him 'Musulman'. And they kind of looked at him funny because I would be wearing shorts or something like that. And they would think like, 'Bad Muslim, why are you letting your wife walk around the island in shorts?' So, it was very interesting, but then when we spoke, and they saw that we were American, then our position changed. It was quite interesting considering the indentured situation there. I think, in a lot of ways, there seems to be more focus on the Indo experience of indentureship that passed through there. And they actually have pretty great records. They have cards that have some photographs of some of the people that passed through Mauritius, and then more dispersed into the Caribbean. But I can't find those things with, with the Sino Mauritians. There's a lack of archiving of anything having to do with Malagasy descendants, or East African descendants that were enslaved. There is such a heavy focus on the Hindu population that I feel like a lot of the rest of the communities within the country are ignored.

\section{TLG:}

I'm hearing so many linkages between Suriname, Guyana, Trinidad and Tobago, Jamaica. It feels like the conversation around indentureship becomes so segregated and racialised whereas our hope with the journal is to focus on it as an institution. We want to talk about how there were indentured Africans, there were indentured Chinese, because the history of the institution tends to be dominated as being about a specific nation or ethnic group.

\section{AC:}

The other thing I don't understand about the shaming aspect of it is that, you know, former slaves were not allowed to purchase land, the 
way indentured Indians or Chinese were allowed to purchase land and other islands. So, shame someone for not having that opportunity? And then to, you know, demean them as being lazy, or savage or whatever. It's such an unfair critique. You know, I think indentureship was essentially slavery. But the difference was that they had the opportunity to acquire land. And that is such a powerful thing. And I think that, you know, that a lot of people forget about that, like, what it means to acquire land. And years later what that does for you, in the sense of, like, attaining wealth. So, it's, it's really unfortunate. Because, I mean, I know that Trinidad and Guyana have, like this history of, you know, violence between the two communities. We're all colonised, though, and you have to look at it in a bigger picture of we all suffered, and we all need to find a way to, you know, work together.

\section{TLG:}

My final question returns to poetry. 'A Litany for Survival' is something that you're referencing by Audre Lorde. Could you speak then to the poetics of what it means that 'we were not meant to survive'? How does this play a role in how you think about gestation and Black women as midwives? Anything you want to say about survival, midwives, inheritance and a kind of maternal inheritance.

\section{AC:}

I know Black people are the most resilient people I've ever met. There's only so much that I can take, but I am constantly amazed at the women who've taken way more than me, have taken like two lifetimes of abuse and can still keep going. One of the most resilient people I've ever met is my mother-in-law. Damn, that woman has had a hard life, and she keeps going, and she does it with such grace. I've never met anyone as graceful as she is considering the amount of abuse and just horrible things that she's experienced as a woman. And she's the sweetest, nicest, most amazing person that I've met. And I'm 
very blessed to have a mother-in-law like that, as opposed to having a mother-in-law that hates my guts for marrying her child. But I really agree with the fact that Lorde says that, you know, we definitely were not meant. We weren't meant to survive any of this and yet we continue to go on and on. And I think the thing that's amazing about, you know, Black folks in particular is that we have a way of taking things and sort of turning on its head as a way to survive.

You know, my interest in midwives is not just that they birth children, but they also provided abortions. That is another method of survival, whether you want to, you know, look at it that way or not. They didn't want, you know, they provided a service for a woman who didn't want their children to suffer. I'm really fascinated with that right now and have, you know, [been] doing a lot of reading on that. But also, they were powerful, you know, they could they have the ability to heal, and they have the ability to kill. A lot of the plantation owners were terrified of them. So rather than, like, really mess with them, they would rent them out. And I think that that's a very powerful position to find yourself in. And you know, what you do with that is, you know, on you, but I just think that, that that's an amazing position and power to have. And, you know, power doesn't always look like what we think it might look like. But that's amazing. That's amazing that you can do that.

\section{TLG:}

Right, and I feel like the ocean has the power too and I'm looking at A Litany for Survival, Only to Meet Nothing that Wants You, your artwork. Could you say a bit about your uses of blue and the cyanotype process and why you chose that title?

\section{AC:}

I mean, I love Audre Lorde, just like everyone else, and I had been, you know, using one of her other quotes, 'You can't dismantle the master's house using the master's tools.' That was a huge inspiration 
for a series of work that I did. And I just wanted to read a little bit more about Lorde, I'm often really pessimistic. I see a lot of people throwing up quotes by her and Baldwin, and I'm thinking, have you actually read the work. But I really wanted to take the time to read.

And I do connect with her and she's also Caribbean. So, with the cyanotypes, I'm fascinated with the effort that was put into colonising. So, I kind of look at cyanotypes in a sense of like blueprints and like sort of acknowledging that they were used for that, but also used to document botanical life. So, a lot of the earlier cyanotypes were of things like corals and, and flowers and seaweed, like Anna Atkins did a whole folio of seaweed. So that was sort of like the origin of a lot of the cyanotype pieces. And the thing that I picked corals for is that they're thinking about coral bleaching, and I was thinking process wise, like, I learned a lot from the lionfish, in regards to process and what I could do with the chemicals, like it's just an endless amount of play, like you can use salts to create spots within the chemicals that it almost looks like you're in space, which was a comment that I received a lot from people when they saw the lionfish installations. As you can also use water to, you know, create water drops or sprays.

So, it looks kind of like an ocean spray, you can use hydrogen peroxide. I mean, there's like, endless amounts of things that you can do with it. And I love that process. It's so much fun, like you can layer the negatives on top of each other, and you'll get like all kinds of crazy, you know, crazy variations of colour. So, I like to play in that way. Like you can create motion and all kinds of stuff with it, it's just like endless. So, I also like the idea of corals and thinking about coral bleaching and how our impact of sort of destroying the environment, but also thinking a lot about how corals are so regenerative and that if you give them the time, they can rebuild their own colony. And even within one coral you have your own colony and just thinking of like life and trying to rebuild and not wanting to focus so much on you know, the sadness of slavery and colonialism but this idea of being regenerative and like regrowing and changing and being able to thrive. So that's where the inspiration for that series of work came 
from. So, with litany for survival, I created this collage of various corals. And then on top of some of them, I've painted sugar on them. So, for the duration of the exhibition, the sugar would crystallise and harden. And some of it would fall off, and some of it would stay put. And, you know, I have no idea what's going to happen, I kind of just leave it up to chance. I like that the viewer has to come in multiple times to see the work to see what exactly is going to happen.

\section{TLG:}

That's something I really love about your work, because it is about regeneration. But it's also about ephemerality. And I just love that that's part of your design. Thank you, Andrea. 